\title{
Social Entrepreneurship: The Role of Institutions
}

\author{
Mukesh Sud \\ Fairfield University, msud@fairfield.edu \\ Craig V. VanSandt
}

Amanda Baugous

Follow this and additional works at: https://digitalcommons.fairfield.edu/business-facultypubs

Copyright 2009 Springer-Verlag

The original publication is available at http://www.springerlink.com/content/ u803173967632151/

\section{Peer Reviewed}

\section{Repository Citation}

Sud, Mukesh; VanSandt, Craig V.; and Baugous, Amanda, "Social Entrepreneurship: The Role of Institutions" (2009). Business Faculty Publications. 80.

https://digitalcommons.fairfield.edu/business-facultypubs/80

\section{Published Citation}

Sud, Mukesh, VanSandt, Craig V., \& Baugous, Amanda, (2009). "Social Entrepreneurship: The Role of Institutions." Journal of Business Ethics, 85 (Supplement 1), pp. 201-216. DOI: 10.1007/s10551-008-9939-1

This item has been accepted for inclusion in DigitalCommons@Fairfield by an authorized administrator of DigitalCommons@Fairfield. It is brought to you by DigitalCommons@Fairfield with permission from the rightsholder(s) and is protected by copyright and/or related rights. You are free to use this item in any way that is permitted by the copyright and related rights legislation that applies to your use. For other uses, you need to obtain permission from the rights-holder(s) directly, unless additional rights are indicated by a Creative Commons license in the record and/or on the work itself. For more information, please contact digitalcommons@fairfield.edu. 


\title{
SOCIAL ENTREPRENEURSHIP：THE ROLE OF INSTITUTIONS
}

\author{
Mukesh Sud \\ Augustana College \\ $63938^{\text {th }}$ Street \\ Rock Island, IL 61201-2296 \\ mukeshsud@augustana.edu \\ p 309-794-7399 \\ f 309-794-7605 \\ Craig V. VanSandt \\ Augustana College \\ 639 38th Street \\ Rock Island, IL 61201-2296 \\ craigvansandt@augustana.edu \\ p 309-794-7334 \\ f 309-794-7605
}

Amanda M. Baugous

Augustana College

639 38th Street

Rock Island, IL 61201-2296

amandabaugous@augustana.edu

p 309-794-7340

f 309-794-7605 


\section{SOCIAL ENTREPRENEURSHIP: THE ROLE OF INSTITUTIONS}

Mukesh Sud - Dr. Sud is currently an Assistant Professor of Management at Augustana College in Rock Island, Illinois. An engineer by profession, he has been an entrepreneur in the Thermal Spraying field. After exiting from his business he completed a Ph.D. in 2006, from the Indian Institute of Management, Bangalore. Dr. Sud's doctoral work has been in the field of corporate entrepreneurship and emerging markets. Besides social entrepreneurship his research has focused on the impact of failure both at the individual and firm level. Dr. Sud has published papers in the Academy of Entrepreneurship Journal and IIMB Management Review.

Craig V. VanSandt - Dr. VanSandt obtained his Ph.D. from Virginia Tech, and is currently an Associate Professor of Management at Augustana College in Rock Island, Illinois. He has authored papers that have appeared in Law \& Policy, Business and Society, Journal of Business Ethics, International Journal of Organization Theory and Behavior, Journal of Management Education, and a book chapter in Systematic Occupational Health and Safety Management. Dr. VanSandt's research interests include organizational climate's effect on employee behavior, the role of business in society, and ethical issues of corporate governance.

Amanda M. Baugous - Dr. Baugous obtained her Ph.D. in Industrial/Organizational Psychology from the University of Tennessee, Knoxville, and is currently an Assistant Professor of Management at Augustana College in Rock Island, Illinois. She has authored papers that have been presented at Society for Industrial and Organizational Psychology, Industrial/ Organizational Psychology \& Organizational Behavior, and North American Management Society conferences. Dr. Baugous's research and consulting interests include the design, evaluation, and implementation of employee selection and performance management systems. 


\title{
SOCIAL ENTREPRENEURSHIP: THE ROLE OF INSTITUTIONS
}

\begin{abstract}
A relatively small segment of business, known as social entrepreneurship (SE), is increasingly being acknowledged as an effective source of solutions for a variety of social problems. Because society tends to view "new" solutions as "the" solution, we are concerned that SE will soon be expected to provide answers to our most pressing social ills. In this paper we call into question the ability of SE, by itself, to provide solutions on a scope necessary to address large-scale social issues. SE cannot reasonably be expected to solve social problems on a large scale for a variety of reasons. The first we label the organizational legitimacy argument. This argument leads to our second argument, the isomorphism argument. We also advance three other claims, the moral, political, and structural arguments. After making our arguments, we explore ways in which SE, in concert with other social institutions, can effectively address social ills. We also present two examples of successful ventures in which SEs partnered with governments and other institutions.
\end{abstract}




\title{
SOCIAL ENTREPRENEURSHIP: THE ROLE OF INSTITUTIONS
}

\author{
"We can't solve problems by using the same kind of thinking we \\ used when we created them." (attributed to Albert Einstein)
}

There is no question that the world today faces numerous and severe problems. One need not expend much time or effort to encounter them in the popular press - global warming, poverty, increasing economic inequality, famine, potential pandemics, ethnic cleansing, terrorism, etc. In addition to the specific problems we face, the virtual collapse of communism and the effects of unbridled capitalism have exacerbated social injustices (Wolman and Colamosca, 1997). Finding and implementing solutions to these problems is becoming critical to our continued survival as a species (Carson, 1962; Gore, 2006).

Business, particularly a relatively small segment known as social entrepreneurship (SE), is increasingly acknowledged as an effective source of solutions for a variety of social problems (Mair, Robinson, and Hockerts, 2006; Nicholls, 2006). Because society tends to view "new" solutions as "the" solution, we are concerned that SE will soon be expected to provide comprehensive answers to our most pressing social ills. In this paper we call into question the ability of SE, by itself, to provide solutions on a scope necessary to address large-scale social issues. Certainly, there is anecdotal evidence that social entrepreneurs have addressed and helped resolve many social problems (e.g., Bornstein, 2004; Leadbeater, 1997; Nicholls, 2004; Nicholls, 2006; Nicholls and Cho, 2006). They have done so by being innovative, marketoriented, and socially focused (Nicholls and Cho, 2006). But, to date, these successes have been achieved locally and on a relatively small scale. 
We will argue that as attempts are being made to scale up the field, SE by itself, is inadequate to address the extent and complexity of the social problems we currently face; nor should it be expected to do so. We do not make these arguments because we do not believe that SE should address social issues. We are certainly not Friedman disciples, of the mind that the sole social responsibility of business is to increase its profits (Friedman, 1970)—with one exception, as we will explain later.

\section{WHY SOCIAL ENTREPRENEURSHIP IS NOT ENOUGH}

SE cannot reasonably be expected to solve social problems on a large scale for a variety of reasons. The first we will label the organizational legitimacy argument. This argument is closely related to, but separate from, (and, in many ways, a basis for) our second argument, the isomorphism argument. We will also advance three other claims, the moral, political, and structural arguments. These are depicted in the following model as forces restraining the effectiveness of social entrepreneurship to solve wide-scale social problems.

insert model here

Our legitimacy argument is based on the fact that the very existence of certain types of organizations depends upon the consent of the society in which they are embedded. This acquiescence is based on the perception that a type of organization serves some sort of useful purpose. For example, for-profit corporations are embraced by American society today, but were highly discouraged and limited during the founding of the United States (Kelly, 2003; Nace, 2003; Grossman and Adams, 1993). Christian churches were all but obliterated in the USSR, 
while they thrive in the United States. Private colleges are common in the United States, but virtually non-existent in western European countries.

Organizational legitimacy, in the context of this argument, is a generalized perception or assumption that the actions of an entity are socially desirable, proper or appropriate within some socially constructed system of norms, values, beliefs and definitions (Suchman, 1995). From an institutional perspective, legitimacy is the means by which organizations obtain and maintain resources (Oliver, 1991).

Social enterprises are the most recent organizational form, and as such, are still seeking the legitimacy already accorded their predecessors. Historically, markets (i.e., private, for-profit enterprise) have sometimes failed to provide certain goods or service. In contexts where governments have not stepped in to resolve or ameliorate such failures, non-profits have functioned as a vehicle to make these services available to citizens, thus gaining legitimacy for the non-profit sector. It is important to be aware that the non-profit sector, by definition, has not been driven by monetary profit and is solely concerned with filling the fissures that neither forprofits nor governments have satisfied.

Social enterprises, which represent a fundamental innovation in the non-profit sector, differ from non-profit organizations in terms of their strategies, structures, norms, and values (Dart, 2004) and are considered a rational and functional alternative to public sector funding and philanthropic resource constraints (Dees, Emerson \& Economy, 2001). Just as non-profits originated to address market and government failures, social enterprises are now being formed to address the issues that for-profits, government, and non-profits miss. Scholars have viewed social enterprises and social entrepreneurship as an "encompassing set of strategic responses to 
many of the varieties of environmental turbulence and situational challenges that non profit organizations face" (Dart, 2004).

Early definitions of the field suggest that social entrepreneurs play the role of change agents in the social sector by adopting a mission to create and sustain social value, not just private value (Dees, 1998). Although definitions in this emerging field remain fuzzy (Boschee, 1995; Dees, 1998), more recently there has been a broad acceptance of social entrepreneurship as being an innovative use of resources to explore and exploit opportunities that meet a social need in a sustainable manner. These classifications are closely related to widely accepted definitions of entrepreneurship as the pursuit of opportunities without regard to resources under control (Stevenson, 1985) and the scholarly examination of how, by whom and with what effect opportunities to create goods and services are discovered, evaluated, and exploited (Venkataraman, 1997).

The authors of this paper suggest that the similarities in the accepted definitions of these fields are, in themselves, an indication that social enterprises are closer ideologically to for-profit enterprises than to non-profits. The early emphasis of social entrepreneurs seems to have been targeted towards innovation and using opportunities to create a social impact. However, as the field has gained increasing recognition (i.e., legitimacy), and social entrepreneurs attempt to scale their efforts, the lack of adequate resources increasingly will be felt. The ability to attract and maintain resources is a key element in the search for legitimacy.

The evolving definitions of social entrepreneurship indirectly acknowledge this by emphasizing the sustainability of their efforts. Traditionally non-profits have been funded by a mixture of member fees, government funds, grants and user fees (DiMaggio \& Anheir, 1990). Social enterprises, on the other hand, are attempting to broaden this funding model by making 
"strategic moves into new markets to subsidize their social activities either by exploiting profitable opportunities in the core activities of their for profit subsidiaries or via for profit subsidiary ventures and cross-sector partnerships with commercial corporations" (Nicholls, 2004). The number of stakeholders that social enterprises engage with is hence likely to be larger than those for non-profits. The diverse expectation of these multiple stakeholders and the desire to be self-sustaining is likely to further complicate these relationships. Significantly, philanthropy is becoming more strategic in its largess, with donors calling for objective performance metrics and financial transparency.

The preceding paragraphs describe a typical process - as social enterprises seek to scale their efforts to address social problems, they need to acquire legitimacy as a class of organization. However, in their efforts to bridge the traditional field of for-profit operations and fill in the gaps left by governments and markets (the non-profit sector's accustomed role), financial results tend to subsume the social mission, if not in the social entrepreneur's mind, certainly in the reporting requirements for investors and donors (Bruck, 2006).

An early exemplar of this transition can be observed in the microfinance field. With the arrival of private investment into the sector there have been calls to broaden its scope and multiply its impact. Simultaneously, attempts are being made to reduce its dependence on donors and government funding.

Citigroup, the world's biggest bank, started a microfinance division in 2005. The division's global director commented, "[T]wo and a half billion people ha[ve] never used a bank. Forty percent of the world is beyond the world we know" (Bruck, 2006: 68). As a financial bank, the focus is likely to be on "financial inclusion" [gaining new customers for the bank's services] rather than reducing poverty. Mouhammed Yunus the founder of Grameen Bank and recent 
Nobel Peace Prize winner, observed that the traditional goal of business - maximizing profit - is inappropriate when dealing with the poor. In discussions with Pierre Omidyar of Ebay, who has supported microfinance but called for a self-sustaining profitable model, Yunus said, “[W]hy do you want to make money off the poor people? When they have enough flesh and blood in their bodies, go and suck them, no problem. But, until then, don't do that. Whatever money you are taking away, keep it with them instead, so that they can come out more quickly from poverty" (Bruck, 2006: 3).

We are concerned that the desire to gain legitimacy and avoid dependency on donors may result in unintended consequences in a field still in its infancy. As a hybrid model emerges, we see a blurring of the factors that have traditionally distinguished non-profits from for-profits, such as goals, values, motivators, clientele, and types of clientele focus (Van Til, 1988; DiMaggio and Anheir, 1990). Such a hybrid model may have the drawbacks of both organizational forms with none of their individual advantages. This lateral movement from a pro-social mission to a double (or triple) bottom line, accompanied by a desire to gain legitimacy by emphasizing economic outcomes, may ultimately lead to the premature discrediting of a promising field. Hence, we suggest that the role of institutions becomes critical to ensure that, as the field expands, the desirable outcomes of SE are met, without compromising the essential building blocks on which it has been founded and achieved early success.

Our second assertion is the isomorphism argument. Institutional isomorphism, as originally defined, is “... a constraining process that forces one unit in a population to resemble other units that face the same set of environmental conditions" in which "[o]rganizations compete not just for resources and customers, but for political power and institutional legitimacy, for social as well as economic fitness" (DiMaggio and Powell, 1983: 149-150). In other words, 
organizations in similar fields tend to become more homogeneous over time. Note that the isomorphism argument goes beyond that of the legitimacy argument—not only do organizations need society's approval to exist, but once they obtain that approbation, they are subject to pressures to conform to existing modes of structure and operations.

DiMaggio and Powell (1983) go on to identify three mechanisms through which institutional isomorphism operates: 1) coercive isomorphism—political or social pressures, 2) mimetic isomorphism - responses to uncertainty, one of which is imitation of best practices, and 3) normative isomorphism - processes of rationalization through professional structures. These mechanisms may result from either formal efforts or unofficial, even casual expectations.

We see clear evidence of all three of these mechanisms operating in SE. The rapid proliferation of the field in academia and the emergence of numerous citizen organizations all over the globe will gradually lead to social and political imperatives for conformity. This process will be further accelerated, especially in the context of larger organizations, in their desire for legitimacy and funding to promote their objectives. This point is an integral component of both the legitimacy and isomorphism arguments.

Ashoka, a nonprofit entity organized in 1980, is dedicated to helping social entrepreneurs build networks that will allow dissemination of approaches to resolving social problems. Between 1990 and 2004 its operations spread from eight to forty-six countries, while increasing the number of "Ashoka Fellows" from 200 to 1,400 (Bornstein, 2004). This is a clear example of a formal effort to promote mimetic isomorphism within the SE field. This desire is prompted by the reality that the field is in an initial phase of existence, with few successful models to follow, and a plethora of problems to solve. Finally, normative pressures are now beginning to exert themselves through professional structures within the SE field. Ironically, this pressure is 
emanating primarily from large corporations, which, as they dedicate themselves to the field of $\mathrm{SE}$, are demanding greater accountability in their stated desire to achieve a higher impact (the Bill and Melinda Gates Foundation is probably the best known example). Financial markets are also beginning to play a part in forcing conformity within the SE field, as efforts to establish structured investment exchanges are being developed (Bruck, 2006; Marketplace, 2007). Thus, the theory of institutional isomorphism anticipates that social entrepreneurship initiatives will, over time, increasingly resemble each other.

Nicholls and Cho, however, express concern that isomorphic pressures, inevitable in the scaling process, may hinder the work of SE.

...[C]an social entrepreneurs adopt modes of rationalization and professionalization consistent with the need to escape these [the tendency toward institutional isomorphism] pressures?

... [T] here is an ongoing process of antithesis that is a function of how social entrepreneurs challenge existing, dysfunctional, social welfare delivery structures. Indeed, contra Marx and Hegel, there seems to be no evidence that the move to a final synthesis is either desirable or likely. The more social entrepreneurs continue to avoid institutional isomorphism and sectoral assimilation by defying the logic of Hegelian-Marxian synthesis,... and the more systemic and sustainable social impact they are likely to achieve (Nicholls and Cho, 2006: 116-117).

Although we anticipate that isomorphic forces will, as Nicholls and Cho (2006) predict, inhibit the effectiveness of SE, we also recognize that certain factors will mitigate those forces. These mitigating factors will help SE maintain effectiveness, but they will also limit the scale upon which SE will operate. One such factor mitigating the general operation of institutional isomorphism in the SE field is the very nature of what social entrepreneurs do. SE has been characterized as a form of Schumpeterian entrepreneurship, a disruptive force that acts as “...change agents for society, seizing opportunities others miss and improving systems, inventing new approaches and creating sustainable solutions to change society for the better" (Skoll Foundation, 2005). Certainly, Schumpeterian entrepreneurs are not inherently immune to the forces of institutional isomorphism (e.g., witness the railroad, pharmaceutical, and computer industries; or the multinational firm). All were disruptive agents of "creative destruction" 
(Schumpeter, 1942), but are now relatively homogeneous factors in the economy. However, SE operates in a wide variety of cultures, geographic locales, and social problems, implying that it may not be as susceptible to the forces of institutional isomorphism as are many other industries and organizational forms. "As a consequence, social entrepreneurs can avoid many of the coercive isomorphic pressures typically experienced by other organizations from outside forces....[T]he bespoke diversity of much successful social action plays against mimetic forces and embodies a focus on social objectives rather than organizational form....Using a legitimacy framework to explore the dynamic effectiveness of social entrepreneurship reveals not only their [sic] resistance to institutional isomorphic pressures..." (Nicholls and Cho, 2006: 114-115).

Social entrepreneurs, virtually by definition, are attacking social problems caused by shortcomings in existing markets and social welfare systems (Mair, Robinson, and Hockerts, 2006; Nicholls, 2006). The institutions that comprise these markets and social welfare systems are part of the structure that created those very social problems (refer back to Einstein's quote at the beginning of this paper). Those market and welfare institutions are also clearly much further along in the process of institutional isomorphism than are social entrepreneurs. Their existing power and legitimacy will tend to resist the widespread isomorphism of SE, if for no other reason than to protect their own status.

Although social entrepreneurs may be able to address specific social problems more effectively if they resist the forces of institutional isomorphism, they will also be less likely to bring about the broad and comprehensive reforms needed to bring about widespread solutions to those problems. "They [social entrepreneurs] defy the traditional isomorphic forces that often constrain and categorize organizational innovation...preferring instead constantly to challenge 
the status quo by reconfiguring accepted value creation boundaries (public/private, for-profit/notfor-profit, and economic/social)" (Nicholls, 2006: 11).

Our third argument why SE will be unable to resolve social problems is the moral argument. To fully understand this argument, it is necessary to trace some facets of Western history. The amoral theory of business (Shepard et. al., 1995) is currently the dominant paradigm in our society, one in which the economic institution is viewed as somewhat separate from the other institutions and immune to some moral regulations. This paradigm is the result of the shift, beginning in the seventeenth century, from the "moral-unity" theory of business to the "amoral theory of business" (Shepard et. al., 1995). The moral-unity theory of business postulates that the economic institution is viewed as an integral part of the overall society, and that it is subject to all of the same norms and moral regulations as all of the other social institutions. In contrast, the amoral theory of business sees the economic institution as separate from other social institutions, largely insulated from all of the moral norms followed in the rest of society. It is imperative to note that the moral-unity theory of business, as well as the amoral theory of business, pertain to how people view the economic institution and how they behavenot whether the economic institution is, in fact, normative or amoral.

In this shift, the economic institution has been separated morally in certain significant ways from other social institutions such as the church, the state, the community, and the family. As a result, the economic institution has come to be exempt from some generally accepted norms. Or, as some have stated, the economic norms have become the only ones that matter.

You may prefer to think it's just a leftist structural theory that labor and export market stability are often the underlying reasons for various U. S. sanctions, military actions, and other foreign policies. Or you can just read Investor's Daily Business and the like, when such things are often spelled out explicitly by the players themselves, with remarkably little concept that any other paradigm for human behavior might exist (Harris, 1999: 122-123). 
Shepard et. al. (1995) point to several factors in this shift from the moral-unity to the amoral theory of business. From the earliest Western civilizations, the dominant ideology was uniformly communitarian. In ancient Greece, the prevailing view was that individuals existed only within the context of the overall society and that economic activity was a necessary evil, useful only to provide the necessities of life. Early Christians held views similar to the Greeks on the relation between the individual and economic activities. With the birth of Jesus and the establishment of the Christian church (then the Catholic Church), most Western societies were unified under the domination of the church, clearly representing the moral-unity theory. A significant turning point came with the Protestant Reformation, and its notion that individuals could have a direct relation with their God, without the intervention of the church. This novel idea laid the groundwork for the first true recognition of the individual as an entity separate and apart from society. Calvinism and its revolutionary idea of predestination inadvertently provided further impetus for the acceptance of economic activity, and for the first time, approved the accumulation of individual wealth - albeit towards the end of communitarian purposes.

Although neither Luther nor Calvin intended to do so, both of their doctrines promoted the acceptability of a more individualistic ideology. This in turn provided fertile ground in which the spirit of capitalism could grow, as documented by Weber (1904-05/1958). Weber viewed the development of rationalism as an integral component of the development of the spirit of capitalism. Along with the Enlightenment's conviction that humans could, through reason alone, solve the puzzles of the universe, it was a short road to the belief that man was his own master (a notion completely foreign to Luther and Calvin). This notion reduced the influence of the church, and gradually, economic activity was placed in a special domain somewhat removed 
from moral rules associated with other social institutions; this separation constitutes the amoral theory of business.

Two major themes arise from this intellectual history. The first is the rise of the individual as an entity separate from the society in which she is situated. Nisbet (1993) refers to this as the process of individualization, or the separation of individuals from communal social structures. The new societies heralded the rise of moral egoism and social atomization. The second theme is the separation of the economy from other social institutions. Beginning with the ancient Greeks, Western civilization had viewed society as composed of unified institutions, including the family, the state, the church, and the economy. However, because of the forces just outlined, people came to see the economy as separate in some ways from other institutions. Both of the processes described by these themes have been instrumental in the rise of the amoral theory of business. In turn, this paradigm is quite possibly a major contributor to the expectation that SE can, by itself, solve many of our current social problems.

Emile Durkheim, like other early sociologists, had seen the effects of the profound disruption of society engendered by the shift just outlined, including the growing separation of the economy from the rest of society: "For two centuries economic life has taken on an expansion it never knew before. From being a secondary function, despised and left to inferior classes, it passed on to one of first rank" (Durkheim, 1937/1996: 11). In Professional Ethics and Civic Morals, Durkheim explored the problems of an advanced, complex society in which the economy had become so detached from other social institutions that it became an end in itself. He wrote that in Western societies neither government nor society held moral sway over the economic institution; a state of anarchy within the economic sphere was therefore inevitable. He made several references to "the anarchy of the economy" in this work (a concept virtually 
identical to the amoral theory of business.) According to Durkheim, "We can give some idea of the present situation by saying that the greater part of the social functions (and this greater part means to-day the economic — so wide is their range) are almost devoid of any moral influence..." (Durkheim, 1937/1996: 29). Durkheim would argue that social institutions external to business must provide effective moral guideposts for SE.

As Victor and Stephens (1994) note, for all intents and purposes, everything and nothing has changed since Durkheim, over one hundred years ago, gave the lectures that now comprise Professional Ethics and Civic Morals. In some ways the milieux are eerily similar. Instead of the Industrial Revolution, we are now undergoing the Information Revolution, and instead of shifting from an agrarian society to an industrial one, we are in the midst of the transition from industrial society to a post-industrial society. Durkheim saw the effects of the transition from an agriculturally based economy to an industrial one, and we are seeing the shift to a service and information-based economy. Finally, we, like Durkheim, are still looking for an institution that can instill morals into the economic institutions; Durkheim was correct when he observed that the market in a capitalistic economy has difficulty imposing a set of moral rules on the participants in that market. As Turner notes, "The problem facing modern Europe [and the United States] is the separation of the economy from society and the absence of any effective regulation of the market place" (Turner, 1996: xxxi). Society today is undergoing many of the same types of social upheavals, with the same types of effects that Durkheim witnessed a century ago. Francis Fukuyama has termed this the "Great Disruption" in the social values that had prevailed in the industrial-age society of the mid-twentieth century.

This period, roughly the mid-1960s to the early 1990s, was also marked by seriously deteriorating social conditions in most of the industrialized world. Crime and social disorder began to rise, making inner-city areas of the wealthiest societies on earth almost uninhabitable. The decline of kinship as a social institution, which has been going on for more than 200 years, accelerated sharply in the second half of the twentieth century. Marriages and births declined and divorce 
soared; and one out of every three children in the United States and more than half of all children in Scandinavia were born out of wedlock. Finally, trust and confidence in institutions went into a forty-year decline (Fukuyama, 1999:55-56).

Durkheim's concern over the social chaos in his time is clearly still relevant today. Within the economic sphere, one of the common indicators of this condition is the continued prevalence of unethical business practices. To expect that any business institution, even SE, can provide the moral leadership needed to resolve multiple, large, complex social problems is simply unreasonable.

In essence, Durkheim anticipated our argument over one hundred years ago. His concern about the effects of the removal of moral constraints on economic behavior mirrors ours. To the extent that the good of all parties is not considered pertinent to economic activities (as is the case under the amoral theory of business), the growth of SE will be retarded.

The fourth reason that SE, as it scales up, is not likely to be an effective solo agent to resolve social problems we refer to as the political argument. Albert Cho (2006) makes the highly relevant point that the "social" in SE is vacuous unless and until it is defined—and the process of definition is, itself, fraught with tensions. Existing definitions of SE are clearly approbative - but they fail to delineate what social ends are being pursued. Until the social end is specified, Cho maintains that it is impossible to make value judgments about the benefits of SE. For example, consider the social end of providing access to abortion procedures. If one happens to be "pro-choice," the existence of a social venture to ensure access to abortion procedures is probably a good thing; but if one is "pro-life," it is anathema.

He also points out that the process of establishing social ends is political, and that the political process is entangled in values; and those values may be different depending on whether they are conceived of in the private or public sphere. Thus, unless the social end pursued by a 
social entrepreneur has been determined through a public political process, that end is simply one person's conception of "the good" (Cho, 2006).

The relevance of Cho's concerns in the current context is that, absent some method of reaching agreement about the desirability of particular social ends, SE is subject to varied degrees of approval and support from entities external to the social entrepreneur. If general support from external bodies is limited (due to disagreement with the social end or alienation from the process of determining the end), SE will not be as effective as it otherwise could be. Thus, at the very least, social entrepreneurs are dependent on processes external to them to set generally approved social goals. "Yet the act of defining the domain of the social inevitably requires exclusionary and ultimately political choices about which concerns can claim to be in society's 'true' interest. These choices reveal that, despite its protestations to the contrary, SE by its very nature is always already a political phenomenon" (Cho, 2006: 36, author's emphasis)

The final argument we advance here is the structural argument. Simply put, this argument states that the very structure of a capitalistic economy works against the idea of SE. The crux of this argument is contained in the inherent tension that all business enterprises face: competitive advantage (i.e., self interest) versus corporate social responsibility (i.e., interest in others' welfare). In more detail, this argument is that the current way we view competition in the marketplace makes it unlikely that business people, even social entrepreneurs, will pursue socially beneficial ends.

The premises and conclusion of the argument are:

- $\quad$ The structure of the American economy has evolved into a bifurcated system of large, powerful companies and relatively small, powerless organizations (Galbraith, 1967). 
- Because of this division in the economic system, the original meaning of competition, as envisioned by Adam Smith (1776/1986), has been bastardized into "winning" or "maximizing profits."

- $\quad$ The emphasis on winning causes self-interested behavior - adherence to ethical egoism.

- $\quad$ Acting in an exclusively self-interested manner (often referred to as ethical egoism) renders integrity impossible (McFall, 1987).

- Therefore self-interested behaviors by business practitioners are more likely to occur than are socially beneficial behaviors (VanSandt, 2002).

The emphasis on "winning" is a cultural phenomenon that is prevalent in the West, especially in America. Alfie Kohn characterizes winning as "a capsule description of our entire culture" (Kohn, 1992: 3). Winning and losing are the central components of structural competition. "To say that an activity is structurally competitive is to say that it is characterized by what I will call mutually exclusive goal attainment....This means, very simply, that my success requires your failure" (Kohn, 1992: 4).

The nascent field of SE studies implicitly recognizes this propensity toward self interest and winning, and the dichotomy between self interested behaviors and other-directed behaviors. “[U]nlike business entrepreneurs who are motivated by profits, social entrepreneurs are motivated to improve society" (Skoll Foundation, 2005). We must acknowledge at this point that we realize that, in some ways, we are calling into question the most basic assumptions about capitalism. Adam Smith is popularly thought to have argued in Wealth of Nations that self interest is the basis upon which an economy creates wealth for all. "It is not from the benevolence of the butcher, the brewer, or the baker that we expect our dinner, but from their regard to their own interest. We address ourselves, not to their humanity but to their self-love, and never talk to them of our own necessities but of their advantages" (Smith, 1776/1986: 2627). 
Smith's supposed reliance on self interest to guide economic activity is understandable when one focuses on personal gain; but the title of his book, Wealth of Nations, reveals his true purpose. Smith hoped to show how an economy could be structured so that it benefited everyone in the nation, not just a few lucky (or hard-working) individuals (Muller, 1993). Unfortunately, he did not provide much in the way of an explanation about how that would work. Instead, he relied on the now famous "invisible hand" explanation to show how self interest would work to benefit all.

\begin{abstract}
But the annual revenue of every society is always precisely equal to the exchangeable value of the whole annual produce of its industry....As every individual, therefore, endeavours as much as he can both the employ his capital in the support of domestic industry, and so to direct that industry that its produce may be of the greatest value; every individual necessarily labours to render the annual revenue of the society as great as he can. He generally, indeed, neither intends to promote the public interest, nor knows how much he is promoting it. By preferring the support of domestic to that of foreign industry, he intends only his own security; and by directing that industry in such a manner as its produce my be of the greatest value, he intends only his own gain, and he is in this, as in many other cases led by an invisible hand to promote an end which was no part of his intention....By pursuing his own interest he frequently promotes that of the society more effectually than when he really intends to promote it (Smith, 1776: 265).
\end{abstract}

Smith's assertion is akin to the cartoon in which one sophisticated mathematician is presenting his proof, with an intermediate step of “...then a miracle occurs," only to be critiqued by another, who says, "I think you should be more explicit here in step two."

insert cartoon about here

Smith failed to provide any support for his contention, and was later contradicted by another economist, who said, "Left to themselves, economic forces do not work out for the best except perhaps for the powerful" (Galbraith, 1973: xiii).

Although there certainly are successful, selfless social entrepreneurs, they are a minute minority of the population. Because these SEs so clearly stand out from the population of 
business entrepreneurs, they are the exceptions that prove the rule inherent in the structural argument - that individual economic gain is the primary motivation for business entrepreneurs. Early research efforts in the field of SE implicitly recognize this by concentrating on: "profiles of 'hero' social entrepreneurs" (Nicholls and Cho, 2006: 99), or by asking if they are "“worldhistorical individuals', heroic men and women 'with insight into what was needed and what was timely', whose 'deeds and...words are the best of their time'?" (Nicholls and Cho, 2006: 106, quoting Hegel, 1988: 32). Expecting that such a small percentage of the population, even if they are truly heroic, can make a sizeable dent in the plethora of social problems is simply unrealistic.

It is equally unrealistic to expect, given the way markets operate, entrepreneurs to be motivated solely to address socially beneficial issues. In one of the examples, which addresses a pressing housing problem in Mumbai, India, an entrepreneur clearly states, "It makes a lot of investment sense for us. We are not here just to serve a social cause" (Architecture for Humanity, 2007). We must strike a note of caution here. Foundations like the Grameen bank have demonstrated that providing financial services to rural communities and microentrepreneurs can be achieved on a sustainable and scalable basis. This has resulted in developments which cause us concern. As we described as part of the legitimacy argument, existing financial institutions have begun to enter the microfinance field. We call into question whether the traditional goal of profit maximization, that these for-profit organizations espouse, is appropriate in dealing with the poor.

\section{HOW THEN SHALL WE PROCEED?}

If SE is not the answer to our social ills, then what is? Certainly not business in general — many argue that it has contributed far more to social problems than it has to alleviating them (Derber, 1998; Ehrenreich, 2001; Kelly, 2003; Korten, 1995; Nace, 2003; Shulman, 2003). 
Governments, in all their various forms, seem almost entirely incapable of "fixing" the social problems their citizens face. Religion appears to have virtually abdicated its influence in the West, along with its emphasis on helping the disadvantaged. "However, the decline of organized religion in some cultures has provided another set of social market failures" (Nicholls, 2006: 9).

It is our contention that no single social institution—an organizational system which functions to satisfy basic social needs by providing an ordered framework linking the individual to the larger culture (Shepard, 2005)—is capable of resolving the large-scale problems now facing us, or those yet to come. It will take the collaborative efforts of many different sectors to effectively address our complex social problems. As Albert Einstein is purported to have said, "Everything should be made as simple as possible, but not simpler." If our social problems cut across institutional boundaries (as they all do), Einstein would tell us that all of those institutions must be involved in the solutions.

Although collaborative efforts among social institutions sounds good on paper, the current imbalance of power may impede their ability to do so. Business, or the economy, is clearly the dominant social institution in the West, and has been for more than two centuries (Durkheim, 1937/1996: 11; Etzioni, 1991). This fact, by itself, is not necessarily indicative of anything. However, problems arise when the "currency" of one social sphere gains influence in another sphere (Walzer, 1983). As an example, consider the influence that money (the currency of the economy) has gained in the political sphere (whose currency ideally includes ideas, justice, and morality). Money's influence in other spheres often manifests itself in the form of a single criterion for decision-making - that of profit, or other form of monetary gain.

SE scholars are fond of talking about the "double" or even "triple" bottom line. We agree with the desirability of such an approach. However, until we acknowledge that only one of 
those lines - monetary profit — really matters to a large majority of decision makers, our calls for more social justice will remain largely unanswered. Other social institutions, especially government, religion, and education must be intimately involved in finding solutions to our social problems. The current imbalance is built into our social structures, as one legal scholar notes, "I realized that the many social ills created by corporations stem directly from corporate law. It dawned on me that the law, in its current form, actually inhibits executives and corporations from being socially responsible" (Hinkley, 2002: 4, author's emphasis).

We mentioned previously that we are not Friedman disciples, except in one instance. His philosophy of corporate social responsibility is summed up in his directive, "...there is one and only one social responsibility of business - to use its resources and engage in activities designed to increase its profits so long as it stays within the rules of the game..." (Friedman, 1962: 133). Currently, for all practical purposes, business makes up its own rules of the game (Kelly, 2003; Korten, 1995; Nace, 2003; Stone, 1975). Until other social institutions provide an effective counterbalance to business's influence, and help develop more just "rules," the second and third bottom lines will continue to be effectively ignored.

\section{HOW CAN SOCIAL INSTITUTIONS WORK TOGETHER?}

James Rest, building on the work of Lawrence Kohlberg and Jean Piaget, developed a model of activities necessary for moral behavior to occur. His Four Component Model specifies that a moral agent must: 1) become sensitive to, or aware of, the moral situation; 2) make moral judgments about the situation; 3) be sufficiently motivated to act, and 4) have courage to follow through with the action. Other than needing to become aware of a moral situation before any of the other steps can occur, Rest is careful to say that his four components do not necessarily occur in sequence, and they are likely to interact (Rest, 1994). This model is a useful tool for 
analyzing the likelihood that moral behavior (in this particular instance, SE) will occur. If the amoral theory of business is accurate, we would expect repeated failure in any and all of the four steps. With business practitioners' moral capabilities artificially truncated, it becomes clear that other social institutions' input is necessary. As one author notes, "Childline [an SE venture in India] and the Grameen Bank could not have achieved national and global impact without the financing and the legitimacy they received from governments" (Bornstein, 2004: 269). Below, we postulate ways in which dissimilar social institutions might use Rest's framework in order to work together to solve social problems.

Awareness - The initial recognition that a social problem exists, and carries with it moral implications, may arise from a plethora of sources. For example, a religious order might recognize that a number of its parishioners need basic medical care. Lacking the ability to provide those services by itself, it might enlist government agencies or SEs to address the problem. Our moral argument clarifies the point that viewing business as an amoral enterprise severely limits the operation of moral awareness. Seeing business as an undertaking with moral implications is necessary for moral awareness to operate.

Judgment - Moral judgment is the topic about which philosophers have been debating for more than two millennia. To assume that SEs, operating in a vacuum, would know the "right" actions to take, gives them much more credit than they are due. As we point out in the political argument, social ends may be highly contentious (take the pro-choice/right to life debate as one example). The process for establishing social ends is necessarily political, and in many cases, would include input from other social institutions, such as the family, religion, or education.

Motivation - As the Skoll Foundation points out on its website, SEs are motivated by more than just the bottom line; they seek to improve society. However, we present the case in 
the structural argument that we cannot rely solely on SEs beneficence. The profit motive is too strong in our society to realistically believe that a subset of the economic institution will be able to bring about widespread social improvements. Therefore, other social institutions like governments, religious orders, and educational systems must become involved to either change societal values or provide a system of rules that guide economic behavior toward more social ends.

Courage - Rest points out, “A person may be morally sensitive, may make good moral judgments, and may place high priority on moral values, but if the person wilts under pressure, is easily distracted or discouraged, is a wimp and weak-willed, then moral failure occurs because of deficiency in Component IV (weak character)" (Rest, 1994: 24) Some of the defining characteristics of SEs are their extraordinary devotion to their causes and their persistence in the face of often overwhelming obstacles (Bornstein, 2004; Nicholls, 2004, 2006). Although these are obviously commendable qualities, they are not a sound basis upon which to build a system of social justice. "We want [people] with moral courage. Yet we must strive to create organizations where moral courage is not needed" (Kidder, 2005: 179). As we have discussed in the isomorphism argument, SEs' ultimate goal is to change the system itself, so that the obstacles they (and more importantly, their clients) encounter cease to exist (Skoll Foundation, 2005; Nicholls and Cho, 2006). Because these obstacles are the products of a wide range of social institutions, all of those institutions must be involved in their destruction.

\section{EXAMPLES}

We have argued that as SE attempts to scale up, it will, by itself, be unable to solve the social problems we currently face. For a variety of reasons, it will take a joint effort by several social institutions to effectively address those issues. As we show in the following examples, 
varied social institutions are working with SEs to address some of the most profound social problems currently faced. These institutions include governments, education systems, and forprofit businesses. These examples provide clear evidence that our arguments are sound, and that such inter-institutional collaboration is a necessary element in addressing our most serious social ills.

\title{
One Laptop Per Child
}

\author{
"This is not just a matter of giving a laptop to each child, as if bestowing \\ on them some magical charm. The magic lies within—within each child, within \\ each scientist-, scholar-, or just-plain-citizen-in-the-making. This initiative \\ is meant to bring it forth into the light of day."
}

\section{Kofi Annan}

Founded in 2005, it has been only a few short years since Nicholas Negroponte presented his vision for a global educational program to the World Economic Forum in Davros, Switzerland. Joined by technological heavyweights, AMD, Google and News Corp, Negroponte outlined his strategy for providing “...children around the world with new opportunities to explore, experiment, and express themselves." Negroponte's organization, One Laptop Per Child (OLPC), has chosen a bold and unique approach for achieving this goal.

The strategy undertaken to reach these ends involves the coordination of experts in technological design and manufacturing, as well as educational research and international relations (representing the social institutions of business, education, and government) to develop a means by which children in underdeveloped nations and communities can enhance their own learning process. Based on research by Seymour Papert, an MIT professor and renowned expert on artificial intelligence and the use of technology in early education, and espoused by Negroponte in his book Being Digital, the organization has developed a rugged, energy-efficient, 
internet-capable laptop, called the XO, installed with software designed specifically to allow children not only access to the world via the internet, but also the capability to manipulate and experiment with programming in order to enhance critical thinking and problem-solving skills.

Though the goals to which Negroponte and the One Laptop Per Child organization aspire to have met with little criticism, it is the strategy executed that has instigated the most controversy and evoked many pressures from outside constituencies that have attempted to inhibit the growth and achievements of the OLPC organization. Negroponte's organization has met with resistance from certain factions within for-profit technology organizations, educational research, and governments of those countries targeted for distribution of OLPC's machines.

Particular resistance stemmed from one of the key goals set forth by the OLPC, to build a computer for less than $\$ 100$. This price point, though recently deemed unachievable, was set in the hopes that such a relatively low price for a fully functioning laptop would allow countries to buy larger quantities of laptops for their own educational systems. However, at the same time, the market has been pressuring laptop manufacturers to lower prices. The existence of a $\$ 100$ laptop concerned many manufacturers who were actively working to lower the price of laptops over a longer term. Moreover, many computer manufacturers were already planning and/or producing laptops designed for children (e.g., Intel and Asus) and had begun attempting to garner market share in developing countries for their own products. The development of the OLPC's XO represents not only a potentially acute downward force on current laptop prices, but also represented direct and vital competition for what has been estimated to be billions of potential customers.

Additionally, the success of the OLPC initiative hinges on the buy-in by the leaders of developing countries. While countries such as Brazil, Urugay, Libya, Rwanda, and others have 
ceremoniously committed to the OLPC cause, follow-through with orders on the magnitude expected by OLPC has fallen short. Moreover, countries aggressively sought out by the OLPC, including India and China have shown wavering interest in the program. In both cases, politically oriented concerns have been raised as to whether or not these countries could use their own advanced technological know-how to create machines within their own countries. To partially counter these obstacles, the OLPC plans to sell XO machines for $\$ 400$ in a "give 1, get 1" campaign within the United States, a marked change in strategy, for a two week period in November of 2007 in order to generate interest and funding to jumpstart the dissemination of the machines in target countries.

Though these are just two of the influential challenges for the OLPC organization, they represent well the conflict experienced by social entrepreneurs as their organizations begin to gain momentum. The more support the OLPC gains in terms of its mission, the more pressure the organization faces to conform to the expectations of powerful, yet unintentional, constituencies. For example, as OLPC began to make progress toward the design and production of a much more durable, efficient, and economical computing machine isomorphic pressure was applied by both the technological and educational industries to mold OLPC's approach into an approach more traditional, and thereby less threatening, model. Moreover, though the leadership of many countries agree, in principle, with the goals of the OLPC organization and realize the potential for significant long-term benefits, they seem to resist the achievement of those goals in ways that do not directly, and in the short-term, benefit those nations. These structural and political pressures created clear and challenging obstacles to the OLPC programs progress.

Recent events have indicated that the OLPC organization is taking action to address these isomorphic, political, and structural pressures. For example, in 2007 the OLPC created a 
position on their Board for a representative from Intel, historically their most staunch and bitter competition. This unlikely collaboration between not-for-profit and for-profit organizations, while surprising many observers, was explained by Negroponte as a way for the OLPC organization to maximize the number of laptops distributed to children around the world.

Additionally, the OLPC organization has responded to political and structural pressures by shifting their marketing strategy from a primary emphasis on persuading national educational and political leaders of target countries to working directly with local and regional leadership of target nations in order to build demand from within. While the outcome of this new strategic approach remains to be seen, early evidence indicates that the OLPC organization may make stronger headway toward achieving its mission. In fact, in October of 2007, after an initial rejection by the Indian government in order to evaluate India's ability to build its own program from within, a pilot program was begun at Khairat School in Khairat-Dhangarwada, a small village in Maharashtra State, India.

\section{Dharavi-The make over of the largest slum in Asia}

The root cause of urban slumming seems to lie not in urban poverty but in urban wealth.

Gita Verma

The operational definition of a slum is poor or informal housing which is characterized by overcrowding, inadequate access to safe water and sanitation, and has insecurity of tenure. The United Nations has estimated that more than a billion people - a third of the urban population-live in slums and that these numbers are expected to swell as the rural exodus continues. 
Dharavi houses close to a million people squeezed into 550 acres of swampy landfill in the center of India's financial capital, Mumbai. Sewage filled gutters (there is a toilet for every 1,440 residents), rickety ramshackle homes, labyrinthine lanes so crowded with shanties that little sunlight penetrates and garbage piles everywhere are a common sight in what is probably Asia's largest slum. This place is booming, however, with sometimes highly polluting industrial activity. A thriving pottery business exists where potters have passed on their craft through generations. Other industries include soap making, chemical manufacturing, and recycling, all of which have existed side by side with sweat shops, in which workers on sewing machines toil for long hours in tiny rooms. It has been estimated that the annual gross revenues of business emanating from Dharavi is approximately $\$ 650$ million.

The residents are also a source of cheap, skilled and unskilled labor that is desperately required to help keep the wheels of India's financial capital moving. However, successive governments' apathy toward their citizens' well-being, the prohibitive cost of housing in the city, and the regular influx of people has further aggravated a serious housing problem. Despite a number of attempts over the past few decades to address this issue and get the squatters evicted from what is now valuable government land, it has remained an intractable problem. This is due in no small measure to the so-called "vote bank politics" prevalent here. Local democratically elected governments have turned a blind eye simply because the densely populated areas serve as a source of votes during elections. A number of attempts, over the years, by the city's slum clearance board have also been unsuccessful.

Historically, slum rehabilitation has been addressed on a piecemeal basis, more often being tackled as a housing, rather than a socio-economic problem. This has resulted in the lack of any sustainable model of rehabilitation. The Dharavi Redeployment Project (DRP), a public/ 
private partnership has adopted a significantly different approach on three fronts. If successful, this model could be a blueprint for slum rehabilitation all over the world.

First, it attempts to treat slum dwellers as a valuable human resource that can act as a cornerstone of a vibrant and robust economy. Unlike previous urban planning initiatives, DRP seeks to integrate slum areas with the rest of the city in order to provide sustainable development. The project recognizes both the need of the slum dwellers to continue their livelihood, as well as the necessity of providing them infrastructure for HIKES (Heath, Income, Knowledge, Environment and Socio-cultural development). Significantly, the plan envisages full deployment of slum dwellers and transit accommodation until the project is completed, within the same areas where they now reside. Attempts are being made to upgrade their skills while maintaining their vocation (e.g., people who for many generations have been engaged in pottery will be provided training to improve their skill sets using other mediums, such as ceramics, while opportunities will be provided to them to market their crafts locally as well as a potential export market).

Secondly, in anticipation of likely moral and structural pressures that might arise, the plan has involved the private sector. International developers have been invited to transform Dharavi into an integrated township with all modern civic amenities and complete infrastructure, including entrepreneurial zones where small businesses could be run. Under the proposal each family would be entitled to a 225 square foot dwelling unit equipped with proper sanitation in mid- and high-rise buildings. Approximately 36.6 million square feet of liveable space will be constructed by the top five bidders, each of whom would be allotted a 107 acre zone. In exchange for providing local inhabitants with free homes and licensed industrial space, the successful builders will have the right to develop an additional 43.5 million square feet in the 
open spaces freed up by relocating the slum dwellers, which they would be allowed to sell or lease commercially.

Finally, the government is confining its role to that of a facilitator. The original idea was conceived by an architect who has since been invited to join the DRP and has been made the project management consultant. To preempt likely political pressures that this model might face NGO's have been entrusted with spreading awareness of the benefits of the scheme and legislation introduced that the slum resettlement proceeds after seventy percent of households sign up for it. The Free Space Index (FSI) also know as FAR, (the square footage of area a builder is typically allowed to construct) has been increased to ensure viability of the project. The government is thus clearly luring private builders both with the promise of huge returns on their investments and the ability to participate in a noble cause.

Traditionally, the common approach for slum development has been for the government to sanction slum clearance and then build low cost housing with public funds. Toshi Noda, Asia Director of the United Nations Human Settlement Program (UN-Habitat) said, "Free apartments is not common. It is a new scheme. I think it will work because the private sector can get their profit by developing the other half of the real estate" (Giridharadas, 2006).

Besides heralding it as a financial "opportunity of a life time" for prospective builders, the Global Expression of Interest highlighted the opportunity to participate in a noble cause with huge social benefits. A director of a New York investment fund was recently quoted in the local media as saying, "It makes a lot of investment sense for us. We're not here just to serve a social cause" (Architecture for Humanity, 2007).

The project, which is now at the bidding phase, is likely to take six to seven years to complete. The Global Expression of Interest advertisement, inviting prospective bidders, was 
published in May 2007. Short listing of bidders is in progress. Simultaneously, an environmental impact assessment in each of the five sectors of the redevelopment is in progress. The initial response from the international community has been overwhelmingly positive with top-flight builders submitting offers, which are in the process of being evaluated. Mumbai's Dharvai makeover is an exemplar of how social entrepreneurship can succeed by engaging other institutions. 


\section{BIBLIOGRAPHY}

Architecture for Humanity, 2007. "Dharavi."

http://www.architectureforhumanity.org/programs/Settlements/dharavi.html.

Bornstein, D. 2004. How to Change the World. New York: Oxford University Press.

Boschee, J. 1995. "Social Entrepreneurship." Across the Board 32(3): 20-5.

Bruck, C. 2006. "Millions for Millions." New Yorker. October 30.

Carson, R. 1962. Silent Spring. Boston: Houghton Mifflin.

Cho, A. 2006. "Politics, Values and Social Entrepreneurship: A Critical Appraisal." In J. Mair, J. Robinson and K. Hockerts (Eds.), Social Entrepreneurship. Houndmills, Basingstoke, Hampshire: Palgrave Macmillan.

Dart, R. 2004. "The Legitimacy of Social Enterprise." Nonprofit Management and Leadership, 14(4) : 411-424.

Dees, J. 1998. "Enterprising Nonprofits.” Harvard Business Review Jan-Feb 55-67.

Dees, J., J. Emerson, and P. Economy. 2001. Enterprising Nonprofits: A Toolkit for Social Entrepreneurs. New York: Wiley.

Derber, C. 1998. Corporation Nation: How Corporations are Taking Over Our Lives and What We can do about it. New York: St. Martin's Griffin.

Di Maggio, P. and H. Anheier. 1990. "The Sociology of Nonprofit Organizations and Sectors." Annual Review of Sociology, 16, 137-159.

DiMaggio, P., and W. Powell. 1983. "The Iron Cage Revisited: Institutional Isomorphism and Collective Rationality in Organizational Fields." American Sociological Review (48). 147-160.

Durkheim, E. 1937/1996. Professional Ethics and Civic Morals. London: Routledge.

Ehrenreich, B. 2001. Nickel and Dimed: On (Not) Getting By in America. New York: Metropolitan Books.

Etzioni, A. 1991. "Reflections on the Teaching of Business Ethics." Business Ethics Quarterly 1 (4). 355-365.

Friedman, M. 1962. Capitalism and Freedom. Chicago: University of Chicago Press.

Friedman, M. 1970. "Social Responsibility of Business." The New York Times Magazine Section. September 13.

Fukuyama, F. 1999. “The Great Disruption.” The Atlantic Monthly (283). 55-80.

Galbraith, J. 1967. The New Industrial State. Boston: Houghton Mifflin.

Galbraith, J. 1973. Economics \& The Public Purpose. Boston: Houghton Mifflin.

Giridharadas, A. 2006. "Not Everyone Is Grateful as Investors Build Free Apartments in Mumbai Slums." New York Times, December 14. http://www.nytimes.com/2006/12/15/business/worldbusiness/15slums.html?_r=1\&oref=s login.

Gore, A. 2006. An Inconvenient Truth. Emmaus, PA: Rodale Press.

Grossman, R., and F. Adams. 1993. Taking Care of Business: Citizenship and the Charter of Incorporation. Cambridge, MA: Charter, Ink.

Harris, B. 1999. Steal This Book and Get Life Without Parole. Monroe, ME: Common Courage Press.

Hegel, G. 1988. Introduction to the Philosophy of History. Indianapolis, IN: Hackett.

Hinkley, R. 2002. "How Corporate Law Inhibits Ethics.” Business Ethics. January/February.

Kelly, M. 2003. The Divine Right of Capital: Dethroning the Corporate Aristocracy. San

Francisco: Berrett-Koehler Publishers, Inc.

Kidder, R. 2005. Moral Courage. New York: W. Morrow. 
Kohn, A. 1992. No Contest: The Case Against Competition revised ed. New York: Houghton Mifflin.

Korten, D. 1995. When Corporations Rule the World. San Francisco: Berrett-Koehler Publishers, Inc.

Leadbeater, C. 1997. The Rise of the Social Entrepreneur. London: Demos.Mair, J. and I. Marti. 2006. "Social Entrepreneurship Research: A Source of Explanation, Prediction, and Delight." Journal of World Business, 41:36-44.

Mair, J., J. Robinson, and K. Hockerts. 2006. "Introduction.” In J. Mair, J. Robinson and K. Hockerts (Eds.), Social Entrepreneurship. Houndmills, Basingstoke, Hampshire: Palgrave Macmillan.

Marketplace. 2007. "Wall Street Donates Its Wisdom.” http://marketplace.publicradio.org. November 2.

McFall, L. 1987. “Integrity.” Ethics (98). 5-20.

Muller, J. 1993. Adam Smith in His Time and Ours: Designing the Decent Society. New York: The Free Press.

Nace, T. 2003. Gangs of America: The Rise of Corporate Power and the Disabling of Democracy. San Francisco: Berrett-Koehler Publishers, Inc.

Nicholls, A. 2004. "Social Entrepreneurship: The Emerging Landscape." In S. Crainer and D. Dearlove (Eds.), Financial Times Handbook of Management, 3 rd ed. Harlow, UK: FT Prentice-Hall.

Nicholls, A. 2006. "Introduction.” In A. Nicholls (Ed.), Social Entrepreneurship: New Models of Sustainable Social Change. Oxford: Oxford University Press.

Nicholls, A. and A. Cho. 2006. "Social Entrepreneurship: The Structuration of a Field." In A. Nicholls (Ed.), Social Entrepreneurship: New Models of Sustainable Social Change. Oxford: Oxford University Press.

Nisbet, R. 1994. The Sociological Tradition. New Brunswick, CT: Transaction Publishers.

Oliver, C. 1991. "Strategic Response to Institutional Processes." Academy of Management Review, 16(1). 145-179.

Rest, J. 1994. "Background: Theory and Research.” In J. R. Rest and D. Narváez (Eds.), Moral Development in the Professions. Hillsdale, NJ: Lawrence Erlbaum Associates, Publishers.

Schumpeter, J. 1942. Capitalism, Socialism, and Democracy. New York: Harper \& Brothers. Shepard, J. 2005. Sociology $9^{\text {th }}$ ed. Belmont, CA: Thomson Wadsworth.

Shepard, J., Shepard, J., Wimbush, J., \& Stephens, C. 1995. "The Place of Ethics in Business: Shifting Paradigms?" Business Ethics Quarterly (5). 577-601.

Shulman, B. 2003. The Betrayal of Work: How Low-Wage Jobs Fail 30 Million Americans and their Families. New York: The New Press.

Skoll Foundation. 2005. www.skollfoundation.org.

Smith, A. 1776/1986. The Wealth of Nations.. In R. L. Heilbroner (Ed.), The Essential Adam Smith. New York: W. W. Norton \& Company.

Stevenson, H. 1985. "The Heart of Entrepreneurship." Harvard Business Review, 85-94.

Stone, C. 1975. Where the Law Ends: The Social Control of Corporate Behavior. New York: Harper Torchbooks.

Suchman, M.1995. "Managing Legitimacy: Strategic and Institutional Approaches." Academy of Management Review, 20 (3) 571-610. 
Turner, B. 1996. Preface to the Second Edition. In E. Durkheim (Author), Professional Ethics and Civic Morals. London: Routledge.

Van Til, J. 1988. Mapping the Third World: Voluntarism in a Changing Social Economy. New York: Foundation Centre.

VanSandt, C. 2002. “A Structural Explanation for Unethical Business Practices.” Unpublished manuscript.

Venkataraman, S. 1997. “The Distinctive Domain of Entrepreneurship Research: An Editor's Perspective. In J. Katz and R. Brockhaus (Eds.), Advances in Entrepreneurship, Firm Emergence and Growth Vol. 3. 119-138. Greenwhich, CT: Jai Press.

Victor, B., \& Stephens, C. 1994. "The Dark Side of the New Organizational Forms: An Editorial Essay." Organizational Science (5). 479-482.

Walzer, M. 1983. Spheres of Justice: A Defense of Pluralism and Equality. United States: Basic Books.

Weber, M. 1904-05/1958. The Protestant Ethic and The Spirit of Capitalism. New York: Charles Scribner's Sons.

Wolman, W., and Colamosca, A. 1997. The Judas Economy: The Triumph of Capital and the Betrayal of Work. Reading, MA: Addison-Wesley Publishing Company, Inc. 


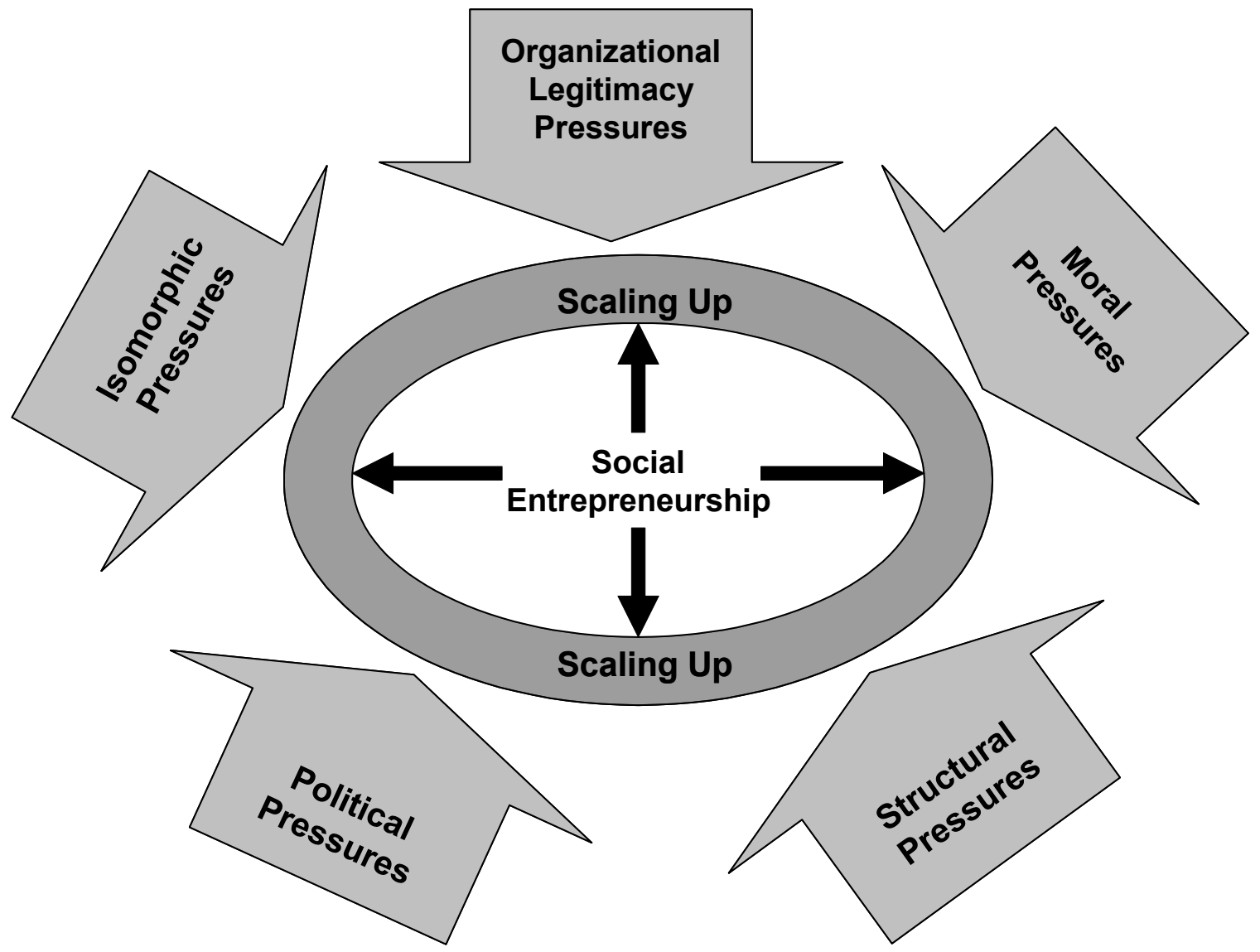




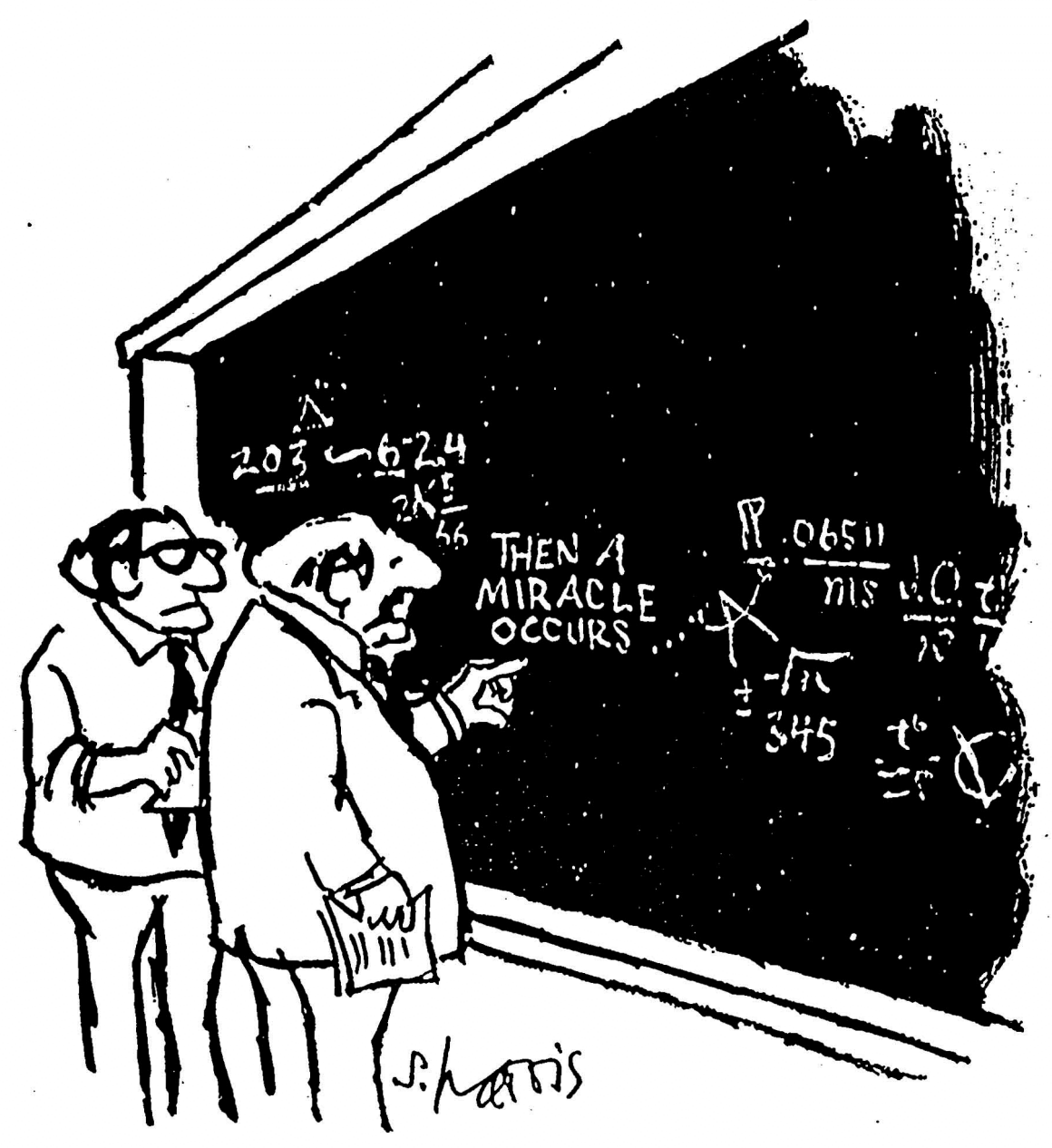

"I think you should be more explicit here in step two." 